\title{
The Personal and the Private in the Piety of the Biblical Psalmist
}

\author{
Danijel Berković \\ The Biblical Institute, Zagreb \\ dberkovic@bizg.hr \\ Dean Slavić \\ Faculty of Humanities and Social Sciences, University of Zagreb \\ dean.slavic@gmail.com
}

UDK: 27-242:27-27:2-18

Original scientific paper https://doi.org/10.32862/k.14.2.4

\begin{abstract}
The work discusses a correlative relationship between the notions of the personal and the private in the context of biblical psalmist's piety. Elements of anthropology (heart, soul, face) will obtain considerable importance, particularly the ideas of face and soul (נפש פנה and a (נה to the Greek idea of $\pi \rho \circ \sigma \pi \omega v$ (prosopon), person. The authors will insist on the distinction between the ideas of personal and private, but they will also recognize the interdependence of these ideas, in recognition that the individual and the societal, are both contributions in the building of the subject as the self. In Paul's Hymn to Love (1 Cor. 13) the complementary nature between the personal and the private is evident. There we find both passive and active subject's role claiming this double aspect of the human subjectpersonal and private. Discussion in this work follows long-term debates over the nature of the subject, its personality, and its privacy.
\end{abstract}

Keywords: psalmist, person, personal, subject, private, heart, face, soul

\section{Introductory Remarks}

It is not uncommon that at a lexical level, some words and notions are regarded as synonyms, even when that is not so. The case is the idea of personal and private; the notions are sometimes regarded as synonyms. Even though the semantic 
fields of the two notions overlap, they cannot be regarded as synonymous. An excellent example of the distinction between the notions of personal and private we will find in the piety of the biblical psalmist. Personal piety of the psalmist may well be manifested within a public religious event but in his privacy, his piety will take some more distinctive forms, as we shall demonstrate in this work.

In this article, we will first make some demarcation lines between the notions of the personal and the private, after that the notions of terms subject and subjectivity. An attentive reader of the Psalter will easily be able to identify himself with the psalmist, hence we ought to give some attention to this issue of appropriation or self-identification and interpretation. Finally, the end of this work focuses on those psalmodic texts which will clearly display the distinctions between the personal and the private aspects of the psalmist piety.

\section{Personal and Private}

The demarcation between the personal and private is significant in examining the Psalmist's individual piety. The two notions may easily be overlooked by regarding them as synonymous. However, the idea of privacy implies a higher degree of confidentiality and intimacy. ${ }^{1}$ The distinction between the personal and the private in the life of biblical psalmist will be more evident in its anthropological aspects.

Psalmodic critical scholarship has not paid adequate attention to the distinction, between the personal and the private, resulting in further lack of insight of this problematic, but also unnecessary disputes in the research of biblical Psalter. The issue has been neglected due to the belief that the terminology of personal and private lacks criteria that will be more scientifically grounded. Although, the conjunction between terms "scientific criteria" and "religiosity" is almost oxymoron. That is why manifestations or expressions of the personal are deemed as subjective, while the impersonal is considered objective (cf. James 1936). ${ }^{2}$ In the dichotomy between the subjective and the objective, the subjective seems to be

1 In the language that we use, we may have "private property" but we do not speak of "private injury," but rather of "personal injury." The injury is referred to be personal, but not private. Privacy considers higher degree of confidentiality. Privacy is an antonym for the official. The psalmist's personal piety may be publicly ("officially") manifest, but in the most intimate experiences and his emotional or emotive states he withdraws into the privacy of his bedroom (cf. Ps. 6:7).

2 William James $(1936,439)$ presents certain conclusions relative to religiosity and personality. Religiosity belongs to personal and personal destiny, while the scientific approach by and large excludes the personal factor. While religion revolves around the "interest of the individual in his private personal destiny," science, on the other hand, "catalogues her elements and records her laws indifferent as to what purpose may be shown forth by them, and constructs her theories quite careless of their bearing on human anxieties and fates." 
at a losing end. It is often followed by such reasoning, which is a plain syllogism, that what is subjective is not objective. This anteriorly puts the subjective in the inferior position. ${ }^{3}$

The issues of personal and private will also make us tackle the subject matter of the subject and subjectivity. The issue and the question of the subject have been one of the central ideas throughout the history of literature and literary theories; philosophy and psychoanalysis; theology and hermeneutics.

\section{Person and Personality}

The very word person is not known in Biblical Hebrew vocabulary. The closest to our understanding and the concept of person/personality is the Hebrew noun נפש (nephesh "soul," "neck"). But even the nephesh as the individual is hardly ever seen as an isolated unit. It always seems to be in interaction with the community rather than the individual per se. It seems to be only an "indefinite extension" of the corporate personality (cf. Johnson 1961, 7-8).

Apart from the Hebrew nephesh, closer to the idea of a person is the Hebrew term פנה (panah "face"). By the look of it, the "face" seems to be a common denominator for the person-personality idea between the Semitic and the IndoEuropean mindset. Etymologically, the bond between the face and the person is a fascinating one. ${ }^{4}$ Aubrey Johnson $(1964,40)$ when speaking of the face and personality, well points out saying that the face "was found to be extraordinarily revealing in respect of man's various emotions, moods, and dispositions." It is not only the expressiveness of the face that is so revealing of the person. It is also its various "fixing" or "turning" in a particular direction that serves for indications of purpose or intentions of the whole person. For example, God will in punishment and retribution "set his face against" his people (Lev. 26:17). ${ }^{5}$ The face then

3 It is fascinating that in the foundation of contemporary natural science this distinction is somewhat present, in the sense that personal is not so radically removed from what is considered objective; today we speak more and more about physics and metaphysics. In the history of contemporary science this is documented in the researches and observations of authorities such as David Bohm, Werner Heisenberg or Alfred North Whitehead. For more on this topic, see: David Bohm (Casuality and Chance in Modern Physics), Werner Heisenberg (Der Teil und das Ganze) or Alfred Whitehead (Science and the Modern World).

4 The word "person" comes from the original Latin noun "persona" (f.) and/or Greek prōsopon (n.) meaning "face." Originally the gk. prosopon was a mask covering the face. In the ancient Hellenistic and Roman theatrical performances, there were masks for covering the dead; "death-masks." Just as there were a great number of masks to represent every possible character, emotion, age and sex.

5 Representative is how the linguistic, and then the theological face-person pair provoked a major division in the history of the Western world. It is indicative that in the Christian patristic times the Trinitarian controversies started with the conception of God's face and Christ as the "prosopon" of God. The face was an obvious "medium of self-expression, or presenting character" (Prestige 1952, 55). 
ceases to be a mere metaphor and metonymy; the prosopon becomes "an external aspect of an object, whether personal or impersonal" (Johnson 1964, 40).

In the Aaronic blessing (Nu. 6:24-26) the prosopon, the person and personality, is in the face (פנה) of the Lord that shines upon his people: "The LORD make his face to shine upon you, and be gracious to you" (Nu. 6:25). Thus, the face of God, that is God himself in person turns towards man, providing his support and life. On the other hand, God can hide his face (Himself) from the psalmist, which makes him panic-stricken (Ps. 30:7; Ps. 13:1). God or God's face hiding from the psalmist has the effect of mortal threat: "Do not hide your face from me

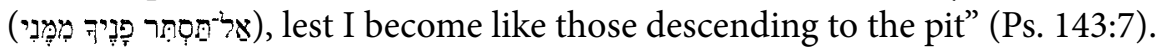

Paul's usage of the word person in his Hymn to Love is revealing. The ultimate knowledge connecting God and a human would be achieved through love only. It would be the relation on the personal and subject's level which is expressed by the words prósopon pròs prósopon (1 Cor. 13:12) - face to face. In Hebrew, rendering here

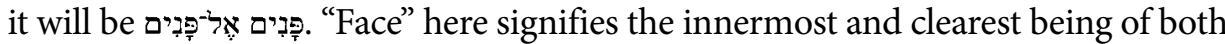
participants. The final cognizance will be freed from mysteries precisely because it will be filled with love on the level of the persons, which means full subjects.

\section{Subject and Subjectivity}

One of the major concerns of literature, both narrative and lyrical literature, relates to the identity and function of the subject. Hence, the dramatis personae (lit. "the masks of the drama") or the main character in a drama; in modern poetry as well, one might be reminded of Eliot and Pound. As a literary genre drama primarily and commonly refers to a theater. ${ }^{6}$ However, in a wider sense drama and dramatis personae may also apply to general situations where an individual subject, or a member of a group, plays a crucial role in an episode. In this, the psalmist in the Psalter is also a dramatis personae. And though the term the "psalmist" is widely being used as terminus technicus, it also ought to be identified in individual terms as the subject.

The interest in the subject and the individual, apart from literary theories, persists in psychoanalysis, hermeneutics, literary criticism, feminist criticism, Marxist criticism, etc. May we be allowed to take as an example from contemporary history how the subject and the individual are determined in the Marxist theory. Jonathan Culler $(2001,109)$ puts it this way: "Marxist theory sees the subject as determined by class position: it either profit from others' labor or labors for others' profit." In a somewhat comparable fashion, the biblical subject can be 
determined by class position, but it is by far more determined by religion. This is where the psalmist as an individual, in his personal and private aspects, needs to be defined and determined. Throughout the psalmodic studies, the subject and the individuality of the individual (psalmist) was one of the key issues. This search for the psalmist as a private individual, against the bias that an individual in the Scriptural context is only an anonymous part of a corporate personality in biblical scholarship, has been around for quite a while.

\section{The Self: Given or Made?}

Before we say some more about the issue of the psalmist as an individual, his personality and privacy, we ought to give at least some attention to the general discussion over various approaches and theories of the subject, not as a grammatical part of a sentence, but rather as an idea of the individuality of the individual. It is a question, whether the subject is "the self something given or something made... and should it be conceived in individual or in social terms' (Culler 2001, 108).

Culler $(2001,109)$ continues and proposes four threads or issues in comprehending of the individual as a subject. Let us briefly outline his scheme. Firstly, the individual can be viewed as the self as something "inner and unique." Secondly, Culler portrays the subject as that which is "made," meaning that the self is "determined by its origins and social attributes." Thirdly, it is a combination of the previous two points. It combines the individual as unique ("inner and unique") and the individual which is "made," determined by its origins. This then emphasizes the changing nature of a self. The fourth and final point, emphasizes that the subject becomes the individual through "various subject positions" or "a series of identification." Observing the Culler's scheme, it strongly directs us to the etymology of the term "subject," but on the other hand, it may impart some oxymoronic shades.

If this Culler's hypothesis that the subject becomes a free individual which identifies himself with a "series of identification" how can we explain that the noun "subject" which comes from the Latin subjectio or subjacceo, where both expressions carry the same idea of submission: subjection "submit, come under" and subjaceo "lie underneath," "at the foot." As we had it so far, the subject comes across as that which is "inner and unique" of the individual. But then the etymology of the term 'subject' gives us a completely different picture, as that which is in submission and not of uniqueness. ${ }^{7}$

7 Culler $(2011,109)$ provides some theories and models regarding the position and the role of the self and the subject. He particularly lists, Michael Foucault's portrayal in psychoanalysis; Marxist theory; the Queer theory, etc. 


\section{Face to Face}

In this etymological predicament, apostle Paul comes to help with his unique expressions in his Hymn to Love (1 Cor. 13) there he recognizes lucidly:

For now we see through a glass darkly; but then face to face: now I know in part; but then shall I know even as also I am known (1 Cor. 13:12).

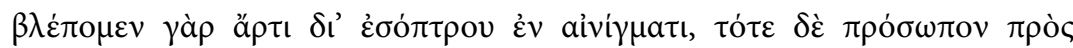

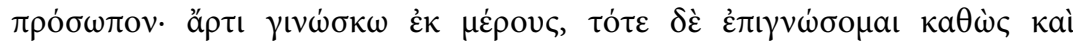
$\dot{\varepsilon} \pi \varepsilon \gamma \nu \omega \dot{\sigma} \theta \eta \nu$ (1 Cor. 13:12).

The apostle does not say clearly here whom or what will be looked at "face to face," but knowing Paul's theological corpus and his Christ-centeredness it is obvious that here we do not read about a gnoseological statement which stands for the fulness of knowledge but about personal "face to face" encounter. It is clear for Paul there is no subject (individual) without another subject (individual). In this case, we do not talk about superiority and submission (subjecio) but about a correlative relationship. There is no knowledge (Heb. ידע) without knowing that other (subject). In Paul's world, there is no human subject without God. In this

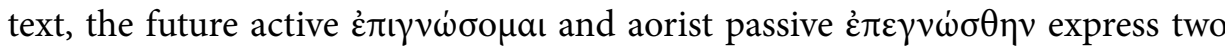
conditions, the active and the passive one, which both contributes to building the subject's nature. The Bible could not and would not speak in the 21 st-century language, but it does not mean the book does not contain knowledge tantamount if not paramount to so-called modern theories.

\section{The Self and "Theoria"}

As we aim to portray the psalmist in his personal and private life, discerning between the subject and the object is very much needed. For the differentiation between the subject and the object, a notion of theory (gk. $\theta \varepsilon \omega p i \alpha)^{8}$ from the ancient Greek metaphysics comes crucial. ${ }^{9}$

The primary meaning of theoria is "to observe" or "to look at." In ancient Greece, theoros or theoroi were official delegates-observers of cities' festivals and theoria was their duty. They were ambassadors from other cities, in diplomatic mission for a truce between the cities. Theoroi were spectators and witnesses, which made theoria not only a duty and the event, but also a stage which is not

8 In contemporary reasoning and thinking the term theory often stands for something that is not practical but theoretical. Our contemporary civilization likes better one other term, the term pragmatism which comes from Greek word pragma ( $\pi \rho \alpha \mu \mu \alpha)$ with the meaning of that "what is done," "practical," "factual" (from lat. factum i.e. what exist, what is real, factual).

9 Theoria is a compound word consisting of: thea "a view" and horan "to see." In his Summa Theologiae, Thomas Aquinas differentiates between subiectum and obiectum and the relationship between the subject and the object. Whereas the object has this capacity (ratio) to evaluate the subject. 
merely an oversight and observation point, but also an observation point wherefrom the observer acquires knowledge. The subject (theoros) as an observer, cannot subject an object to himself if he is in any way subordinate to the object of his observation; thus the theoros had to distance himself from the object of his observation (cf. Biti 1997, 385). ${ }^{10}$

However, there is another, a somewhat different understanding of the theoria as an observation and the affiliation between the subject and the object. Namely, the Latin translation of Greek theoria is speculatio (from Lat. specto, "to observe," "to re-search"). Here, the one who is observing, the observer, is called the spectans, just like the theoros in theoria. But the spectans are also the speculator, i.e. the one who lies in wait, as a researcher. Now comes a significant difference between the observer (theoros) and the Latin observer (spectans). Here comes an etymological play on words, from the Latin verbal root specto also comes speculum, mirror. That is to say that while the spectans is the observer, he is also performing an act of introspection. Indeed, as Biti $(1997,385)$ sums it up in the following way:

speculatio as a Latin translation of the Greek term theoria involves also the final abolishing in the separation between the subject and the object, while and instead they mirror each other... the Greek term theoria in itself equally contains a dimension of observers' separation of subject from object and dimension of self-reflective mirroring of one in other

In this understanding of the ancient Greek theoria, we now have both aspects included, that of the observation (theoros), where the subject is distanced from the object, and a dimension of the introspection and self-reflection, a mirroring between the subject and the object (spectans). Both of these understandings and interpretations of theoria is fully congruent with the psalmist's experiences, where he played a role as an observer (theoros) as well as the experiencer (spectans). We then may conclude that the so-called "theoretical truth" may not be so "theoretical" but rather, based on observation and self-reflection, a phenomenon of life and living. This is well witnessed in the psalmist's personal and private living as we have it in the Psalter. The same process is well expressed in above-cited Paul's Hymn to Love - final knowledge excludes a mirror.

\section{The Self and the Psalmist}

For quite a while in biblical scholarship, particularly in the psalmodic studies, the individual as the subject was predominantly treated merely as a piece in a puzzle, rather than recognized individuality of the individual. Some eminent

10 In Croatia during war in 1990's we had such people from other countries which were part of peacekeeping missions and their primary role was to observe conflicted parties. 
psalmody researchers would claim that individual personality in biblical culture would be equal to arrogance, thus one of the fathers of the psalmodic studies Sigmund Mowinckel $(1962,43)$ will conclude: "To be original, someone apart, a personality, whose right of existence depended on being different, would not to the ancient Israelites have appeared as an ideal or an end to attain, but on the contrary, as a madness, an arrogance, something abnormal, or, in their own words, an unrighteousness and a folly" (italics mine).

As one goes through the biblical texts, there seem to be quite a number of the "abnormal" biblical individuals. To name but two "arrogant" biblical characters, Hannah and Job. Hannah, Samuel's mother, was proclaimed a drunkard; while in her bitterness (מרה נפש) she poured out her grief before God, which resulted in the priest imploring her to sober up (1 Sam. 1:10, 14). ${ }^{11}$ In Job's case, the image of his as the subject - the individual is even more strongly portrayed. If Hannah had her frustrations and sufferings, at the very start of his sufferings, Job strongly expresses his individuality. At the beginning of Job 3, Job curses his life: "After this opened Job his mouth, and cursed his day" (KJV). The expression "his day" (Job 3:1) in the light of Job 3:3 usually is understood as the day of his birth. We ought to take into consideration that nowhere else in the OT the term "his day" stands for the day of birth. Hence, in Job 3:1 it probably refers to the day when everything went wrong for him (cf. Clines 1989, 78-79).

Unless such individuals are to be viewed simply as a record of general traditions or a thematic prototypes. However, even then, as we shall demonstrate there is a case in point of personal anthropology vs. collective anthropology. In the matters of personal anthropology, particularly in the cases of the abdominal idioms, it may prove difficult to put it in the framework of the collective anthropology. Surely, one cannot speak of kidneys, liver, innards, or wombs in the context of collective anthropology.

\section{Appropriation and Interpretation}

An attentive reader of the Psalter will note that comprehension or interpretation of the psalms may not be his ultimate goal. For the attentive reader of the Psalms, the ultimate goal is the appropriation of the psalmodic texts. It is a step further and beyond the necessary intelligent comprehension and interpretation. In this case, the reader is not only to adopt the text in comprehension, competent interpretation, or appraisal of its authoritative value. Appropriation is the reader's

11 On the expression (נפש מרה), "bitterness of the soul," see the discussion by Dermot Cox (1978) in The Triumph of Impotence. 
adoption of the text as if it is one's own, it is a matter of self-identification (cf. Schökel 1998, 90).

Perhaps the best example of appropriation is Jesus' self-identification with the psalmist. It is a powerful display of the last weeks of his life, in Gethsemane experience (cf. Ps. 22) and finally in his death on the cross (Ps. 31). For a better and more adequate perception of the Psalter and the Psalmist, we propose that the appropriation of the Psalms is a better way of mastering and understanding of the Psalter. ${ }^{12}$ We acknowledge that the Psalter is an editorial collection, composed and compiled for liturgical purposes, but we also recognize that it aims to be an appropriation material. This brings us to tackle the issue of the psalmist as a private individual and the subject matter of appropriation.

\section{Personal Piety and Privacy}

\section{Personal Piety}

Personal refers to everything that is immanent to a particular person, whether material (property) or immaterial (emotion). The personal is a combination of each individual's emotional and behavioral patterns. The consciousness and self-consciousness of all that is personal, includes forms of public expression. The Psalmist often yearns to exercise his devotion and piety in public worship. One such example is Psalm 27 (cf. 61:4) wherein his heartfelt yearning for the nearness of God, the psalmist seeks to affirm his faith and exercise his deep-seated personal piety in public worship: "One thing I ask of the LORD; this I seek: To dwell in the LORD'S house all the days of my life, To gaze on the LORD'S beauty, to visit his temple" (Ps. 27:4 NAB)

Some commentators call this kind of psalmodic poem a "spiritual song." Gunkel $(1998,346)$ categorizes the psalm as the "spiritual cult-free psalm" and assembles a collection of 12 such psalms. ${ }^{13}$ However, it is not quite clear why he concludes, oddly, that the collection has "no relationship to the worship service." Others insist that the psalm should be interpreted in the context of the liturgy (cf. Craigie $1983,231)$. Gunkel $(1998,346)$ concludes that this collection of spiritual songs or spiritual cult-free Psalms is "suitable for private use because they consist of genres for the individual." Others, however, do not recognize the earthly exercise of personal piety, but rather consider it as "eternal bliss with YHWH in heaven," where the "Lord's house" designates a divine heavenly habitation (cf. Dahood 1965, 167).

12 We agree and concur with Alonso Schökel $(1998,90)$ saying that biblical psalms are "an extreme, and almost inevitable case of appropriation."

13 Pss $7 ; 16 ; 17 ; 25 ; 26 ; 27 ; 28 ; 32 ; 33 ; 34 ; 35 ; 37$ 
Whichever of these interpretations we accept, the psalmist clearly and powerfully demonstrates his piety, which he wishes to show publicly (cf. Ps. 27:6b).

\section{Privacy}

On the other hand, that which is private is confined to the person concerned, and not publicly expressed. It requires private space, "taken away" (Lat. privatus) from public eyes. In Biblical Hebrew, there are two concepts of the awareness and perception of what is strictly private. One is to do with the verb (boš "to be ashamed") which designates something to be kept strictly to oneself, that what is intimate. Sometimes it refers to the "private parts" of the human body (cf. Deut. 25:11).

The other is verb לוט (lat) לאט (lat "to cover," "hide," "to be secret" or "keep in private"). ${ }^{14}$ Privacy is a matter of seclusion and secrecy (balat). In the conspiratory effort to get rid of David, king Saul in 1 Samuel 18:22 says the follow-

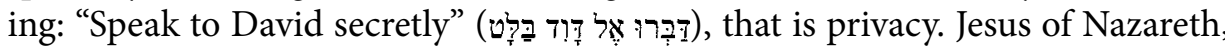
the Jewish rabbi, urged his pious compatriots and followers to exercise genuine personal piety in private. ${ }^{15}$ Such as we find in the Gospel of Matthew: "When you pray, go to your inner room (tamei/on), close the door, and pray to your Father in

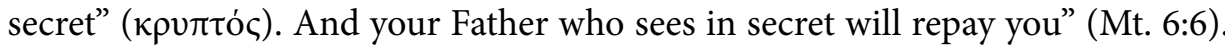

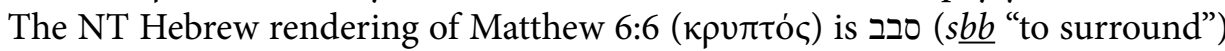
and (str "to hide") which indicates privacy (cf. HNT Salkinson-Ginsburg Hebrew NT) ${ }^{16}$ By using a compound expression of the two verbs סתר סביבו conveys this privacy even in a more intense way than the original Matthean Greek. ${ }^{17}$

The Psalmist's personal piety is often exercised in such privacy. For him, this can be designated spatially and temporally. Spatially, on his bed or a couch, his room (cf. Ps. 6, 63). Temporally, it can be at all times or day and night (cf. Ps. 6, $16,17,42,63,77,88)$.

\section{Concluding Remarks and Further Perspectives}

Although it may seem as being a contradiction, while the collective is being recognized as a ruling social organization, at the same time and that point the in-

14 cf. 2 Sam 19:5. The לאט is hapax legomena.

15 Such "private meeting" with their God involves seclusion - entering into private space and closing the door behind.

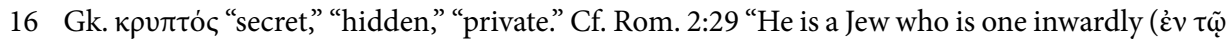
$\kappa \rho \cup \pi \tau \tilde{\omega})$, and real circumcision is a matter of the heart, spiritual and not literal".

17 This also echoes the enclosures of monastic foundations (Lat. claustrum, Eng. cloister) which separate and seclude the pious from the outside world. 
dividual is being recognized as a subject to be concerned with. In the words of Andre Lacocque $(1979,235)$ this can be summed up in his commentary to the Book of Daniel:

Man became a citizen of the world, of the oikumene. And in a paradoxical, yet comprehensible way, this enlarging of men's horizons to universal dimensions had the consequence of atomizing society into individuals. In the process of the disintegrating of social structures which had been second nature to him, man found himself alone, hence unique, with particular problems which could no longer be resolved by collective solutions.

Following Lacocque's summary of how the collective and the individual interact, we conclude that the collective "I" and the collective personality of biblical Isra$\mathrm{el}$, is in coexistence with that which is personal and private. We cannot accept, that the Israelite individual in his/her individuality is to be viewed as arrogance, madness, and something abnormal (cf. Mowinckel 1962, 43). It is possible to demonstrate that the two, the collective and the individual in his/her individuality are not mutually exclusive but rather, being complementary (cf. Lacocque 1979, 235). Paul's Hymn to Love is helpful again, while the subject uses interdependently both the first person singular and the first person plural. Yet the further investigation should encompass the look into some characteristics of the Israelite religion and early Judaism to observe what type of faith is it and what is the nature of the Hebrew religion.

\section{Literature}

Biti, Vladimir. 1997. Pojmovnik suvremene književne teorije, Zagreb, Matica hrvatska

Clines, David. 1989. Job 1-20. Dallas: Word Books.

Cox, Dermot. 1978. The Triumph of Impotence. Roma: Universita Gregoriana Editrice.

Culler, Jonathan. 2001. Književna teorija: vrlo kratak uvod. Zagreb: AGM.

Dahood, Mitchell. 1965. Psalms (I): 1-50. New York: Doubleday.

Gunkel, Herman. 1998. Introduction to Psalms: the Genres of the Religious Lyric of Israel. Macon: Mercer Univerity Press.

James, William. 1936. The Varieties of Religious Experience. New York: The Modern Library.

Johnson, Aubrey. 1961. The One and the Many in the Israelite Conception of God. 2nd edition. Cardiff: University of Wales Press.

Johnson, Aubrey. 1964. The Vitality of the Individual in the Thought of Ancient 
Israel. 2nd edition. Cardiff: University of Wales Press.

Lacocque, Andre. 1979. The Book of Daniel. London: SPCK.

Mowinckel, Sigmund. 1962. The Psalms in Israel's Worship. Oxford: Basil Blackwell.

Prestige, George Leonard. 1952. God in Patristic Thought. London: SPCK.

Schökel, Luis Alonso. 1988. A Manual of Hebrew Poetics. Rome: Pontifical Institute of the Bible.

Solar, Milivoj. 1979. Teorija književnosti. Zagreb: ŠK.

Danijel Berković i Dean Slavić

\section{Osobno i privatno u pobožnosti biblijskog psalmista kao pojedinca}

\section{Sažetak}

U ovom se radu promišlja korelacija pojmova osobno i privatno u kontekstu osobne i privatne pobožnosti biblijskog psalmista. Elementi antropologije (srce, duša, lice) ovdje zauzimaju prvorazredno mjesto, posebno uvidom u biblijsko korištenje pojmova lice i duša (panah i nefeš), što uvelike korenspodira grčkom pojmu $\pi \rho \circ \sigma o \pi \omega v$ (prosopon) - osoba, persona (engl. person). Autori ustrajavaju na distinkciji pojmova osobno i privatno, ali prepoznaju uzajamnost i međuovisnost para: osobno - privatno. Primjereno ovom radu, autori se referiraju i na tekst svetog Pavla u njegovoj Himni ljubavi (1 Kor 13), gdje se zorno ističu aspekti osobnog i privatnog u dvojakoj ulozi, kako pasivnog tako i aktivnog aspekta pojedinca (subjekta). Rasprava rada slijedi mnogogodišnje diskusije i propitkivanja vezane uz distinkciju osobnosti i privatnosti, ali dodaje i svoj obol glede osobe i osobnosti, subjekta i subjektivnosti, ovdje u kontekstu biblijskog psalmista. 